\title{
FORMULATION AND ASSESSMENT OF NUTRIENT CONTENTS OF COMPLEMENTARY FOODS FROM FERMENTED, SPROUTED, AND TOASTED MAIZE-SOYBEAN BLEND
}

\author{
Ademulegun, T.I. ${ }^{1}$, Alebiosu I., ${ }^{2}$ Adedayo, O.E. ${ }^{3}$, Abraham, M.L. ${ }^{4}$, and ${ }^{*}$ Olanrewaju, O.I. ${ }^{3}$ \\ ${ }^{1}$ Department of Animal Health and Production Technology, Rufus Giwa Polytechnic, Owo \\ ${ }^{2}$ Human Nutrition and Dietetics Department, Afe Babalola University, Ado-Ekiti, \\ ${ }^{3}$ Nutrition and Dietetics Department, Rufus Giwa Polytechnic Owo, Ondo State \\ ${ }^{4}$ Nutrition and Dietetics Department, Federal Medical Centre, Gusau, Zamfara State \\ *Correspondence Authors: tunakinsmentoring@gmail.com
}

\begin{abstract}
Background: Provision of quality complementary foods is one of the fundamental ways of fostering the all-around development of a child and preventing long-term nutritional problems.

Objective: The study assessed the nutrient contents of formulated complementary foods from fermented, sprouted and toasted maize-soybean blend

Methods: Maize and Soybean were purchased from Kings Market in Owo Local Government while a commercial complementary food was purchased from Ceci supermarket, Akure Ondo state. The two grains were subjected to sprouting, toasting and fermentation, and the grains were ground into flours and then formulated into nine (9) different blends using the ratio 70:30 for maize and soybean flour respectively. Samples were analysed for proximate and mineral contents while sensory evaluation was carried out using a 9-point hedonic scale. Analysis of variance (ANOVA) and Duncan's New Multiple Range Test (DNMRT) was performed using Statistical Package for Social Science (SPSS) version 23. The difference is considered statistically significant at $\mathrm{P}<0.05$.

Results: The results showed that the protein, fat, and energy contents of sprouted, toasted, and fermented products ranged $(15.67 \%$ to $20.39 \%),(9.79-15.18 \mathrm{~g})$, and $(435.96 \mathrm{kcal} / \mathrm{g}$ to $469.69 \mathrm{kcal} / \mathrm{g}) \mathrm{respectively}$. These values were higher than the protein and energy content of the control sample of $15 \%, 9 \%$, and $398 \mathrm{kcal} / \mathrm{g}$ respectively. The protein value of any of the blends was significantly $(\mathrm{P}<0.05)$ higher than the WHO recommendations of 9.1-13g/day but lower in mineral content. Likewise, iron and iodine were significantly $(\mathrm{P}<0.05)$ higher in the blends than the commercial food

Conclusion: The results showed that maize-soy blends contained a high amount of protein, fat, carbohydrate, iron, iodine, and potassium irrespective of the processed method adopted and can provide better nutrition for infants during complementary feeding.
\end{abstract}

Keywords: Complementary food, maize, soybean, nutrients, sensory attributes

\section{INTRODUCTION}

The problem of undernutrition among children below 5 years of age remains unacceptable throughout the world with large numbers of the affected children being in developing countries (1-2). The problem of malnutrition in many infants starts during or after introduction of complementary foods, contributing significantly to the high prevalence of malnutrition in children less than 5 years of age (3-4). Exclusive breastfeeding for the first six 6 months is the ideal nourishment for a full-term infant by healthy and wellnourished mothers (5-6). However, breast milk cannot sustain the nutrient and calories requirements of infant after the age of 6 months; this gives room for the introduction of complementary foods that can meet the nutritional requirement of the growing child (7-8). In Nigeria, like many other developing countries, there are various complementary foods that have been developed and served to infants in various localities (9-10) Complementary feeding is defined as the process when breast milk is no longer sufficient to meet the nutritional requirements of infants and therefore other foods and liquids are needed along with breast milk (12). According to World Health Organization (WHO) recommendations, the transition from exclusive breast feeding and/or infant formula feeding to complementary food, referred to as complementary feeding, typically covers the period from $6-24$ months of age, and is very vulnerable period. This is because, after 6 months of age, the contribution from human milk becomes progressively insufficient as a unique nutrient source in relation to the optimal requirements for growth and thus, a greater demand is placed on the complementary food part of the diet (13).

In Nigeria, malnutrition during complementary feeding is mainly attributed to low-nutrient dense foods which are given to children as complementary foods. Complementary foods are foods other than breast milk introduced to an infant from age 6 months to provide additional nutrients (14). In Nigeria, children are normally given gruels that is either mixed with boiled water or boiled with water mainly from starch tubers like cocoyam, sweet potato or on cereals like maize, millet and sorghum (15).

The complementary foods developed based on cereal and starchy root have been associated with the incidence of acute malnutrition among infants (16-17). This accounts for more than $25 \%$ death rate in infants in developing countries. Complementary foods produced from cereals are known to be deficient in certain essential amino acids (lysine and tryptophan) 
which are required for the adequate growth and healthy living of infant (17).

Apart from the problem of inadequate nutrients plaguing the complementary food produced from cereals, high dietary bulk and high viscosity are factors which affect the quantity of food a child could consume per meal; this invariably affect the quality of the nutrients available to the children (18). The complementary food that will support growth and maintain good healthy living must contain adequate nutrients and be of low viscosity. The problem could be solved using malting and other processing methods (9).

Several strategies may be used to improve the nutritive value of complementary foods. The traditional complementary food could be improved by combining locally available food that complement each other in such a way that the new pattern of amino acids created by this combination is similar to that recommended for infants (19). The processing technique used for this purpose has been largely fermentation, sprouting/germination and less often toasting. Fermentation enhances the nutritive value of food by increasing vitamin B-complex and perhaps protein content as a result of microbial activity (19). Ademulegun and Koleosho (19) and Lopez et al. (20) noted that minerals were made more available and phosphorus was released from phytate during fermentation of corn. Fermentation and germination can reduce the high bulk of traditional complementary food by reducing the viscosity of the cereal gruel or porridge (19). Toasting reduces the viscosity of gruel, inactivates lipase and increases the shelf life of weaning food. Against this background, effects of sprouting, toasting and fermentation on nutrient contents and sensory characteristics of Maize-Soybean complementary food for infants were investigated in this study.

\section{MATERIALS AND METHODS}

\section{Procurement of Raw Materials}

The raw materials were dried yellow maize and soybean. The raw materials were purchased from the King's Market, Owo Local Government Area of Ondo State. The Maize and Soybean were separately subjected to sprouting, fermentation, and toasting. The commercial complementary food was purchased from Ceci supermarket, Akure, Ondo State

\section{Preparation of sprouted maize and soybean flour}

The Maize grains and Soybean seeds were separately cleaned by hand, sorted and floated to remove broken grains and extraneous materials. The grains and seeds were separately soaked for 24hours at ambient temperature. The hydrated grains were drained and spread thinly on a wet jut bag and covered with another layer of jut bag. The grains and seeds were germinated for three days with watering every six (6) hours. Ungerminated grains were discarded while the sprouted ones were oven dried $\left(50^{\circ \mathrm{C}}\right.$ for 12 hours) and devegetated before milling to flour, sieved and packaged in air tight container and kept in a refrigerator prior to analysis (Fig 1)

Preparation of fermented maize and soybean Flour The Maize grains and Soybean seeds were separately sorted by removing stones and other physical contamination. This was followed by cleaning the separately sorted maize and soybean with water. It was then steeped into water for three (3) days for fermentation to occur. The separately fermented Maize and Soybean was wet- milled using attrition mill and then sieved. This was allowed to settle overnight, the maize and soybean slurry was put in clean muslin cloth and squeezed to remove the water and was then oven dried ( $50^{\circ \mathrm{C}}$ for 12 hours), milled and packaged in air tight container and kept in a refrigerator prior to analysis (Fig 1)

\section{Preparation of Toasted Maize and Soybean Flour}

The maize grains and soybean seeds were separately sorted to remove all extraneous materials. The cleaned maize and soybean were toasted using frying pan on a cooking gas for 30minutes until golden brown coloration of the both the maize and soybean was achieved. The roasted maize and soybean were milled using attrition milling machine in ratio to fine particle, sieved and packaged in air tight container and kept in a refrigerator prior to analysis (Fig 1)

\section{Formulation of maize-soybean complementary foo blends}

Table 1 shows the flour formulation of the maize soybean flour complementary food in 70:30 ratios respectively.

Table 1: Formulation of Maize-Soybeans complementary foods

\begin{tabular}{lll}
\hline Samples & Maize $(\%)$ & \multicolumn{1}{c}{ Soybean $(\%)$} \\
\hline A & $70 \%$ toasted maize flour (TMF): & $30 \%$ toasted soybean flour (TSF) \\
B & $70 \%$ toasted maize flour (TMF) & $30 \%$ fermented soybean flour (FSF) \\
C & $70 \%$ toasted maize flour (TMF) & $30 \%$ sprouted soybean flour (SSF) \\
D & $70 \%$ fermented maize flour (FMF): & $30 \%$ toasted soybean flour (TSF) \\
E & $70 \%$ fermented maize flour (FMF): & $30 \%$ fermented soybean flour (FSF) \\
F & $70 \%$ fermented maize flour (FMF): & $30 \%$ sprouted soybean flour (SSF) \\
G & $70 \%$ sprouted maize flour (SMF): & $30 \%$ toasted soybean flour (TSF) \\
H & $70 \%$ sprouted maize flour (SMF): & $30 \%$ fermented soybean flour (FSF) \\
I & $70 \%$ sprouted maize flour (SMF): & $30 \%$ sprouted soybean flour (SSF) \\
\hline
\end{tabular}


Journal of Dietitians Association of Nigeria (JDAN) Volume 12. December, 2021 Print ISSN: 2141-8209; eISSN: $2635-3326$

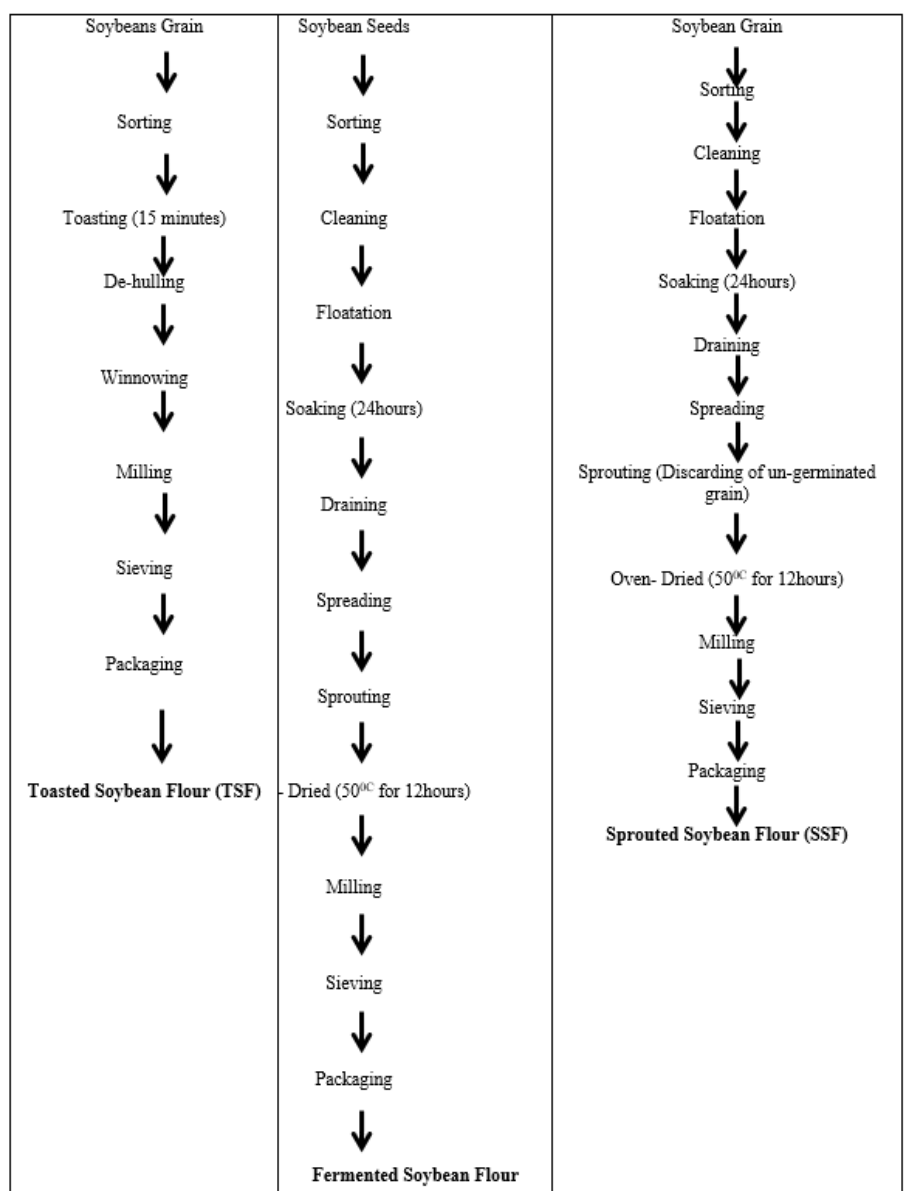

Figure 1: Flow chart for the production of soybean flour

\begin{tabular}{|c|c|c|}
\hline $\begin{array}{l}\text { Maize Grain } \\
\downarrow \\
\downarrow \\
\downarrow \\
\text { Toasted Maize Flour (TMF) } \\
\downarrow \\
\text { Packaging }\end{array}$ & Faize Grain & Ovaize Grain \\
\hline
\end{tabular}

Figure 2: Flow chart for the production of maize flour 


\section{Proximate analysis of formulated complementary foods}

The ash, protein, crude fibre, fat and moisture contents of the formulated complementary foods were determined using the standard methods described by AOAC (21). Total carbohydrate was calculated as the difference between 100 and the sum of the percentages of ash, protein, crude fibre, fat and moisture (22). The sample energy value was calculated from the percentages of crude protein, total carbohydrates, and total fat. The conversion factors used were $9 \mathrm{kcal} / \mathrm{g}$ for total fat, $4.0 \mathrm{kcal} / \mathrm{g}$ for protein and carbohydrates respectively (23).

\section{Determination of mineral contents of the formulated complementary foods}

The mineral contents were determined in a dilute solution of the ashed samples according to the method outlined in AOAC (21) by Atomic Absorption Spectrophotometer (AAS) (210 bulks scientific) for Calcium, Iron, iodine and Zinc while potassium was by flame photometry and phosphorus was determined by calorimetric method.

\section{Preparation of gruel from the blends}

A preparation method described by Amadi et al. (2019) was modified and adopted for the preparation of gruel for the sensory evaluation of this study. One hundred grams of different composite flours was put separately into a bowls and half a litre of water poured into it and stirred until uniform slurry was formed. The slurry was further cooked on a gas cooker with the gas knob at low heat for 15 minutes. Fifty grams (50) was added to each of the gruel and stirred very well with a clean table spoon. The samples were kept in a flask to maintain the serving temperature $\left(15^{\circ} \mathrm{C}\right)$ for sensory evaluation

\section{Sensory evaluation of the formulated complementary foods}

A structured questionnaire was used to collect information from 20 panelists on the sensory characteristics of the complementary food samples. The CF samples were coded as A to I and presented to the panelists who were nursing mothers recruited from Rufus Giwa Polytechnic, Owo. The panelists were seated comfortably at the sensory unit of the department and each panelist was served with separate cup of gruel made from the formulated $\mathrm{CF}$ at the same temperature $\left(15^{\circ} \mathrm{C}\right)$ eaten with tea spoon. The panelists were given a bottle of potable water to rinse their mouth after each tasting. The panelists evaluated the gruel made from the formulated $\mathrm{CF}$ and the control (cerelac) samples for colour, taste, aroma and general acceptability using the five-point hedonic scale where the highest score was 5 and 1 was the least score (24). The extent to which gruel was liked was expressed as: like very much (5), like moderately (4), like slightly (3), dislike slightly (2), dislike very much (1).

\section{Statistical Analysis}

The results were expressed as mean \pm standard deviation of triplicate result and the test for statistical significance was carried out using one-way analysis of variance (ANOVA). The Statistical Package for Social Sciences (SPSS, Version 20) software was used to determine significant differences. Significant means was separated using Duncan's New Multiple Range Test (DNMRT) and differences was considered significant at $\mathrm{p}<0.05$

\section{RESULTS}

\section{Proximate blend formulation of Maize-Soy complementary foods}

Table 2 shows the proximate composition of the complementary composite flours. The sample H and D had the highest $(20.39 \%)$ and lowest $(11.45 \%)$ protein respectively and was significantly $(\mathrm{P}<0.05)$ than the other samples while sample $\mathrm{E}$ and I was significantly (P $>0.05)$ higher in fat $(15.18 \%)$ and ash $(2.29 \%)$ content respectively compared to other samples. On moisture content, sample $\mathrm{G}$ has the lowest moisture content value $(4.95 \%)$ but has no significant difference with sample $\mathrm{H}$, I, and A while sample B has the highest value $(5.99 \%)$ when compared to other samples but has no significant difference with sample A, C, D, E and F. The samples also show a significant difference $(\mathrm{P}<0.05)$ in terms of carbohydrate in which sample D $(70.53 \%)$ had the highest value while sample B $(64.15 \%)$. The energy content ranges from (435.96- $469.69 \mathrm{kcal} / \mathrm{g})$ no significant difference $(\mathrm{P}>0.05)$ between sample A $(442.59 \%)$ and $\mathrm{C}(441.32 \%)$ while significant difference $(\mathrm{P}<0.05)$ was observed in other sample. The control sample was significantly $(\mathrm{P}<0.05)$ lower in energy compared to the formulate blends. 
Table 2: Proximate Blend Formulation of Maize-Soy Complementary Foods

\begin{tabular}{|c|c|c|c|c|c|c|c|}
\hline \multicolumn{8}{|c|}{ Proximate composition (\%) and Energy (Kcal) } \\
\hline Samples & Moisture & Protein & Crude Fat & Fiber & Ash & CHO & Energy \\
\hline $\mathbf{A}$ & $5.52 \pm 0.05^{\mathrm{abc}}$ & $16.64 \pm 0.02^{\mathrm{f}}$ & $10.65 \pm 0.04^{\mathrm{f}}$ & $0.93 \pm 0.00^{\mathrm{cd}}$ & $1.75 \pm 0.00^{\mathrm{d}}$ & $69.67 \pm 0.05^{b}$ & $442.59 \pm 0.22^{\mathrm{f}}$ \\
\hline B & $5.99 \pm 0.58^{\mathrm{a}}$ & $19.69 \pm 0.07^{b}$ & $14.42 \pm 0.11^{\mathrm{b}}$ & $0.88 \pm 0.01^{\mathrm{e}}$ & $0.86 \pm 001^{g}$ & $64.15 \pm 0.03^{\mathrm{h}}$ & $465 \pm 0.630^{\mathrm{b}}$ \\
\hline $\mathbf{C}$ & $5.85 \pm 0.01^{\mathrm{ac}}$ & $18.75 \pm 0.27^{\mathrm{d}}$ & $10.37 \pm 0.09^{\mathrm{g}}$ & $0.92 \pm 0.00^{\mathrm{d}}$ & $2.02 \pm 0.01^{\mathrm{b}}$ & $68.24 \pm 0.11^{\mathrm{e}}$ & $441.32 \pm 0.73^{\mathrm{f}}$ \\
\hline D & $5.87 \pm 0.14^{\mathrm{a}}$ & $11.45 \pm 0.12^{\mathrm{h}}$ & $11.45 \pm 0.12^{\mathrm{d}}$ & $0.85 \pm 0.01^{\mathrm{f}}$ & $1.65 \pm 0.02^{\mathrm{e}}$ & $70.53 \pm 0.01^{\mathrm{a}}$ & $447.83 \pm 1.08^{\mathrm{d}}$ \\
\hline $\mathbf{E}$ & $5.85 \pm 0.02^{\mathrm{ab}}$ & $18.73 \pm 0.06^{\mathrm{d}}$ & $15.18 \pm 0.02^{\mathrm{a}}$ & $0.77 \pm 0.02^{\mathrm{g}}$ & $0.78 \pm 0.02^{\mathrm{h}}$ & $64.54 \pm 0.12^{\mathrm{g}}$ & $469.69 \pm 0.03^{\mathrm{a}}$ \\
\hline $\mathbf{F}$ & $5.93 \pm 0.11^{\mathrm{a}}$ & $17.50 \pm 0.04^{\mathrm{e}}$ & $11.13 \pm 0.05^{\mathrm{e}}$ & $0.83 \pm 0.01^{\mathrm{e}}$ & $1.92 \pm 0.02^{\mathrm{c}}$ & $68.54 \pm 0.13^{\mathrm{d}}$ & $444.28 \pm 0.23^{\mathrm{e}}$ \\
\hline $\mathbf{G}$ & $4.95 \pm 0.01^{\mathrm{c}}$ & $17.33 \pm 0.08^{\mathrm{e}}$ & $10.11 \pm 0.09^{\mathrm{h}}$ & $0.97 \pm 0.01^{b}$ & $2.03 \pm 0.02^{b}$ & $69.57 \pm 0.19^{c}$ & $438.54 \pm 0.45^{\mathrm{g}}$ \\
\hline $\mathbf{H}$ & $5.07 \pm 0.01^{\mathrm{c}}$ & $20.39 \pm 0.13^{a}$ & $13.84 \pm 0.01^{\mathrm{c}}$ & $0.89 \pm 0.00^{\mathrm{e}}$ & $1.16 \pm 0.02^{\mathrm{f}}$ & $67.82 \pm 0.07^{f}$ & $461.01 \pm 1.05^{\mathrm{c}}$ \\
\hline I & $5.29 \pm 0.05^{\mathrm{bc}}$ & $19.15 \pm 0.02^{\mathrm{c}}$ & $9.79 \pm 0.03^{\mathrm{I}}$ & $0.95 \pm 0.01^{b c}$ & $2.29 \pm 0.02^{\mathrm{a}}$ & $67.82 \pm 0.07^{f}$ & $435.96 \pm 0.11^{h}$ \\
\hline $\mathbf{J}$ & $2.5 .00 \pm 0.10^{\mathrm{d}}$ & $15.00 \pm 0.10^{\mathrm{g}}$ & $9.00 \pm 0.10^{\mathrm{J}}$ & $7.00 \pm 0.10^{\mathrm{a}}$ & $2.30 \pm 0.10^{\mathrm{a}}$ & $64.20 \pm 0.10^{\mathrm{g}}$ & $398.00 \pm 0.10^{\mathrm{I}}$ \\
\hline
\end{tabular}

\section{Mineral Composition of the Formulated Maize-Soy Complementary Food}

Table 3 shows the mineral composition of the formulated flour blends and commercial complementary food. The calcium content of the commercial complementary food (control) was significantly different $(\mathrm{P}<0.05)$ higher than all the blends composite flour. Sample A, D and G was not significantly different $(P>0.05)$ from each other in terms of calcium content while sample $\mathrm{B}, \mathrm{E}$ and $\mathrm{H}$ was extremely lower in calcium content (3.51$3.55 \mathrm{mg} / 100 \mathrm{~g}$ ). The potassium content of the formulated blends was appreciably high ranges from (284.33$481.86 \mathrm{mg} / 100 \mathrm{~g}$ and significant difference $(\mathrm{P}<0.05)$ exist between then but lower than the content of the commercial product of $570 \mathrm{mg} / 100 \mathrm{~g}$ ). The iodine content of all the blends were higher than the content of the commercial product and significant difference $(\mathrm{P}$ $<0.05)$ existed between A, B, D, E, G and I while sample $\mathrm{C}, \mathrm{F}$ and $\mathrm{H}$ had similar value with control $(\mathrm{J})$. In the same vein, all the blends samples had a higher value of Iron content than the control $(\mathrm{J})$ value, except in sample A. Iron content were extremely higher and significant difference $(\mathrm{P}<0.05)$ in sample $\mathrm{H}$, I and B to other samples. The phosphorus $(480 \mathrm{mg} / 100 \mathrm{~g})$ and Zinc $(6 \mathrm{mg} / 100 \mathrm{~g})$ content value of the control sample was significantly $(\mathrm{P}<0.05)$ higher than the blends samples.

Table 3: Mineral Composition of the Formulated Maize-Soy Complementary Food

\begin{tabular}{lcccccc}
\hline \multicolumn{7}{c}{ Mineral element $(\mathbf{m g} / \mathbf{1 0 0 g})$} \\
\hline Samples & Calcium & Potassium & Phosphorus & Iron & Zinc & Iodine \\
\hline A & $55.60 \pm 0.13^{\mathrm{b}}$ & $413.85 \pm 14.95^{\mathrm{c}}$ & $61.18 \pm 0.17^{\mathrm{g}}$ & $8.11 \pm 0.07^{\mathrm{h}}$ & $1.55 \pm 0.04^{\mathrm{g}}$ & $91.05 \pm 0.22^{\mathrm{d}}$ \\
$\mathbf{B}$ & $3.55 \pm 0.03^{\mathrm{d}}$ & $294.13 \pm 0.06^{\mathrm{e}}$ & $86.89 \pm 0.19^{\mathrm{e}}$ & $20.12 \pm 0.04^{\mathrm{c}}$ & $1.16 \pm 0.02^{\mathrm{h}}$ & $92.76 \pm 0.37^{\mathrm{c}}$ \\
$\mathbf{C}$ & $37.56 \pm 0.18^{\mathrm{c}}$ & $481.86 \pm 0.09^{\mathrm{b}}$ & $128.98 \pm 0.10^{\mathrm{c}}$ & $17.66 \pm 0.07^{\mathrm{d}}$ & $1.80 \pm 0.02^{\mathrm{d}}$ & $81.57 \pm 0.04^{\mathrm{e}}$ \\
$\mathbf{D}$ & $55.54 \pm 0.13^{\mathrm{b}}$ & $404.19 \pm 14.73^{\mathrm{c}}$ & $51.46 \pm 0.07^{\mathrm{h}}$ & $15.36 \pm 0.03^{\mathrm{i}}$ & $3.49 \pm 3.86^{\mathrm{b}}$ & $90.59 \pm 0.61^{\mathrm{d}}$ \\
$\mathbf{E}$ & $3.54 \pm 0.02^{\mathrm{d}}$ & $284.33 \pm 0.18^{\mathrm{f}}$ & $77.17 \pm 0.05^{\mathrm{f}}$ & $17.37 \pm 0.09^{\mathrm{e}}$ & $0.95 \pm 0.01^{\mathrm{i}}$ & $92.29 \pm 0.71^{\mathrm{c}}$ \\
F & $37.54 \pm 0.18^{\mathrm{c}}$ & $472.20 \pm 0.31^{\mathrm{b}}$ & $119.26 \pm 0.14^{\mathrm{d}}$ & $14.91 \pm 0.03^{\mathrm{f}}$ & $1.60 \pm 0.01^{\mathrm{f}}$ & $81.11 \pm 0.38^{\mathrm{e}}$ \\
G & $55.51 \pm 0.13^{\mathrm{b}}$ & $430.55 \pm 14.93^{\mathrm{bc}}$ & $77.47 \pm 0.04^{\mathrm{f}}$ & $14.12 \pm 0.01^{\mathrm{j}}$ & $2.28 \pm 0.10^{\mathrm{d}}$ & $99.52 \pm 0.59^{\mathrm{b}}$ \\
H & $3.51 \pm 0.03^{\mathrm{d}}$ & $310.81 \pm 0.05^{\mathrm{e}}$ & $103.18 \pm 0.02^{\mathrm{e}}$ & $24.11 \pm 0.02^{\mathrm{a}}$ & $1.87 \pm 0.00^{\mathrm{e}}$ & $101.23 \pm 0.16^{\mathrm{a}}$ \\
I & $37.51 \pm 0.18^{\mathrm{c}}$ & $398.58 \pm 17.21^{\mathrm{cd}}$ & $145.27 \pm 0.11^{\mathrm{b}}$ & $21.66 \pm 0.10^{\mathrm{b}}$ & $2.51 \pm 0.00^{\mathrm{c}}$ & $90.04 \pm 0.17^{\mathrm{d}}$ \\
J & $550.00 \pm 0.10^{\mathrm{a}}$ & $570.00 \pm 0.10^{\mathrm{a}}$ & $480.00 \pm 0.10^{\mathrm{a}}$ & $10.00 \pm 0.10^{\mathrm{g}}$ & $6.00 \pm 0.10^{\mathrm{a}}$ & $80.00 \pm 0.10^{\mathrm{e}}$ \\
\hline
\end{tabular}

Values are mean \pm standard deviation of triplicate analyses. Values with the same superscript in the same column are statistically not significant at $(\mathrm{P}<0.05)$. Key: $A=70 \%$ Toasted maize: $30 \%$ Toasted soybean, Sample B $=70 \%$ Toasted maize: $30 \%$ Fermented soybean, Sample C $=70 \%$ Toasted maize: $30 \%$ Sprouted soybean, D = 70\% Fermented maize: 30\% Toasted soybean, E $=70 \%$ Fermented maize: 30\% Fermented soybean $\mathrm{F}=70 \%$ Fermented maize: $30 \%$ Sprouted soybean, $G=70 \%$ Sprouted maize: $30 \%$ Toasted soybean, $H=70 \%$ Sprouted maize: $30 \%$ Fermented soybean, $\mathrm{I}=$ $70 \%$ Sprouted maize: $30 \%$ Sprouted soybean, J=100\% commercial complementary foods 
Table 3: Recommended dietary Allowance and the nutrients composition of formulations

\begin{tabular}{llll}
\hline Nutrients (100g) & Maize-Soy CF & RDA (6-24months age) & (\%) fulfillment \\
\hline Energy (kcal) & $435-469$ & $834-850$ & $55 \%$ \\
Protein (g) & $11-20$ & $11-13$ & $100 \%$ \\
Carbohydrate (g) & $64.15-70.53$ & 130 & $50 \%$ \\
Fat (g) & $9.79-15.18$ & 30 & $50 \%$ \\
Calcium (mg) & $3.54-55.56$ & 2500 & $1.2 \%$ \\
Potassium (mg) & $294.13-481.86$ & 3000 & $13 \%$ \\
Phosphorus (mg) & $51.46-145.2$ & 3000 & $30 \%$ \\
Iron (mg) & $8.11-24.11$ & 40 & $40 \%$ \\
Zinc (mg) & $0.95-3.49$ & 7.0 & $28.5 \%$ \\
Iodine (mcg) & $81.11-101.23$ & 200 & $47.8 \%$ \\
\hline
\end{tabular}

Source: Dietary Reference Intakes for Energy, Carbohydrate, Fiber, Fat, Fatty Acids, Cholesterol, Protein, and Amino Acids (2002/2005) and Dietary Reference Intakes for Water, Potassium, Sodium, Chloride, and Sulfate (2005). The report may be accessed at www.nap.edu. Copyrighted by the National Academy of Science

\section{Sensory characteristics of maize-soy complementary food}

The sensory evaluation of the gruel made from the formulated flour and commercial flour is presented in the Table 4. The colour rating (4.35) of the control sample $(\mathrm{J})$ which was significantly $(\mathrm{P}<0.05)$ different from other samples was rated best followed by sample A (3.80), B (3.80) and C (3.80). In terms of aroma, taste and general acceptability, the control $\mathbf{J}$ sample lead other samples in the rating as well and significantly $(\mathrm{P}<$ $0.05)$ from the other samples. This was followed by I and A for aroma and General Acceptability respectively. The taste, aroma and general acceptability for sample $\mathrm{J}$ was also scored the highest compared to other samples while significant $(\mathrm{P}>0.05)$ difference was not observed between sample A-I.

Table 4: Sensory characteristics of the complementary foods

\begin{tabular}{lllll}
\hline Samples & Colour & Aroma & Taste & General Acceptability \\
\hline Sample A & $3.80 \pm 1.20^{\mathrm{ab}}$ & $3.10 \pm 0.91^{\mathrm{b}}$ & $2.50 \pm 1.15^{\mathrm{b}}$ & $3.30 \pm 1.00^{\mathrm{b}}$ \\
Sample B & $3.80 \pm 1.28^{\mathrm{ab}}$ & $3.10 \pm 0.85^{\mathrm{b}}$ & $2.60 \pm 1.14^{\mathrm{b}}$ & $3.20 \pm 1.00^{\mathrm{b}}$ \\
Sample C & $3.75 \pm 0.79^{\mathrm{ab}}$ & $2.95 \pm 0.80^{\mathrm{b}}$ & $2.75 \pm 1.00^{\mathrm{b}}$ & $2.85 \pm 1.00^{\mathrm{b}}$ \\
Sample D & $3.80 \pm 1.15^{\mathrm{ab}}$ & $2.85 \pm 1.40^{\mathrm{b}}$ & $2.75 \pm 1.00^{\mathrm{b}}$ & $2.85 \pm 1.00^{\mathrm{b}}$ \\
Sample E & $3.05 \pm 1.36^{\mathrm{b}}$ & $2.95 \pm 0.95^{\mathrm{b}}$ & $3.25 \pm 1.00^{\mathrm{b}}$ & $3.05 \pm 1.00^{\mathrm{b}}$ \\
Sample F & $3.35 \pm 1.04^{\mathrm{ab}}$ & $2.85 \pm 1.04^{\mathrm{b}}$ & $2.90 \pm 1.12^{\mathrm{b}}$ & $3.00 \pm 1.00^{\mathrm{b}}$ \\
Sample G & $3.35 \pm 0.88^{\mathrm{ab}}$ & $2.90 \pm 0.79^{\mathrm{b}}$ & $2.90 \pm 1.07^{\mathrm{b}}$ & $2.95 \pm 1.10^{\mathrm{b}}$ \\
Sample H & $3.70 \pm 1.10^{\mathrm{ab}}$ & $2.85 \pm 1.04^{\mathrm{b}}$ & $2.90 \pm 1.00^{\mathrm{b}}$ & $2.85 \pm 1.00^{\mathrm{b}}$ \\
Sample I & $3.45 \pm 1.40^{\mathrm{ab}}$ & $3.25 \pm 1.07^{\mathrm{b}}$ & $2.90 \pm 1.33^{\mathrm{b}}$ & $3.15 \pm 1.20^{\mathrm{b}}$ \\
Sample J & $4.35 \pm 0.81^{\mathrm{a}}$ & $4.35 \pm 1.35^{\mathrm{a}}$ & $4.50 \pm 1.00^{\mathrm{a}}$ & $4.50 \pm 1.00^{\mathrm{a}}$ \\
\hline
\end{tabular}

Values are mean \pm standard deviation of triplicate analyses. Values with the same superscript in the same column are statistically not significant at $(\mathrm{P}<0.05)$. Key: $\mathrm{A}=70 \%$ Toasted maize: $30 \%$ Toasted soybean Sample B $=70 \%$ Toasted maize: $30 \%$ Fermented soybean Sample C $=70 \%$ Toasted maize: $30 \%$ Sprouted soybean, $\mathrm{D}=70 \%$ Fermented maize: $30 \%$ Toasted soybean, $\mathrm{E}=70 \%$ Fermented maize: $30 \% \quad$ Fermented soybean $\mathrm{F}=70 \%$ Fermented maize: $30 \%$ Sprouted soybean, $G=70 \%$ Sprouted maize: $30 \%$ Toasted soybean, $\mathrm{H}=70 \%$ Sprouted maize: $30 \%$ Fermented soybean, $\mathrm{I}=$ $70 \%$ Sprouted maize: $30 \%$ Sprouted soybean, $\mathrm{J}=100 \%$ Cerelac (Nutrend)

\section{DISCUSSION}

\section{Proximate composition of the samples}

The moisture content was relatively low in all the CF samples. The values obtained in this study were lower than the moisture content (10.03-12.59\%) of complementary food formulated from fermented maize, soybean and carrot flours reported by Barber et al. (25). Moisture content of less than $10 \%$ has been reported to be responsible for the state of non-deterioration in food (26-27). The low value of ash in the processed grains may be as a result of the effect processing on the food sample. The ash content reported here is lower than the recommended values of $(5 \%)$ for infant and young children and that of the commercial complementary food.

All the food samples had high amount of protein, this agreed with other previous researchers $(16 ; 28 ; 29)$. The increased in the protein level was as a result of the inclusion of soya bean. The highest protein value was observed in sample $\mathrm{H}$ might be due to the production of excess amino acids during sprouting and the accumulation in the free amino acid pool and it could also be as a result of mobilization of stored nitrogen of maize to aid sprouting or a compositional change following the degradation of other constituents. This observation was consistent with the findings of researchers who also observed significant increase in protein content with seed sprouting $(30 ; 31)$. The protein was extremely higher when compared to the Recommended Daily Allowance (9.1-13g) for infants within the age bracket of 6-24 months (32). The protein values were higher than that reported by Ojinaka et al. (33), which ranged from (3.9-3.97\%) and the one reported by Amadi et al. (34), in the nutrient and antinutrient composition of yellow maize, Soyabean and date palm fortified by moringa and ginger. Protein synthesis was not affected by the processing methods 
which agree with Matilda (35). Protein is needed for tissue replacement, deposition of lean body mass, growth and because of the rapid growth in infancy protein requirements (36).

Sample E had the highest value of fat compared to other formulated blends and higher than the recommended $10 \%$ for infants. This may not be far-fetched due to the removal of soluble carbohydrates as a result of fermentation. Study had shown that fermentation increases the fat content of complementary food (37). The value obtained in this was higher than the experimental value from fermented maize, rice, soybean and fish meal was $9.38 \%$ and $8.75 \%$ by Amankwah et al. (37). Fat is important in the diets of infants and young children because it provides essential fatty acids, facilitates absorption of fat-soluble vitamins and enhances dietary energy density and sensory qualities as seen in Akinola et al. (39).

Fiber content of the experimental samples was low and this may be associated with the processing methods adopted. Studies had revealed that 0.2 to $2.3 \%$ of fibre in food can decrease due to sprouting and fermentation (40-41). A study by Rusydi et al. (42), opine that the effect of germination on total dietary fibre in different legumes. They reported a significant $(\mathrm{P}<0.05)$ decrease in fiber content of germinated kidney and mung beans which agrees with this current study and also within the range reported $(43 ; 44)$. The low fiber content is an indication for nutrient density and energy needed for the growth of children less than two years (45-47).

\section{Micronutrients composition of the samples}

The experimental samples have appreciable amount of phosphorus, iron, zinc and iodine. Although, the potassium, phosphorus, iron and iodine content of the blended products were lower than the commercial complementary food but can supply $30 \%, 40 \%, 28.5 \%$ and $47.8 \%$ recommended daily intake RDI (table 3 ) needed by the children between 6-12 months of age (32) respectively. Potassium is an essential component known for the role in the stabilization of osmotic pressure and normal $\mathrm{PH}$ equilibrium of the body system (48). Calcium obtained in this study were lower than the value in maize-soy cerelac used as the control but higher than the value $(27.0-47.95 \mathrm{mg} / 100 \mathrm{~g})$ reported for complementary food formulated from malted maize, soybean and groundnut (49). The lower calcium value reported in this study could be attributed to the processing methods that the grains were subjected to prior to analysis (50). Calcium aids in building strong bone and teeth and its deficiency leads to rickets and stunting in children (51). From the sensory evaluation done, it was observed that the control sample was accepted the most in terms of colour, taste, aroma and general acceptability (51). This outcome was expected from the panelist because the nursing mothers are used to feeding their infants with commercial complementary food. However, the formulated blends were significantly accepted from the scores of the results obtained.

\section{CONCLUSION}

Supplementation of maize and soybean flours improved the macronutrients and micronutrients contents. This study shows that maize-soybean complementary foods which are processed using the three processing methods (sprouting, fermentation and toasting) can be consumed by children from 6 months of age. Sample H had high appreciable of amount of potassium, phosphorus, iron and iodine while sample $H$ had the highest amount of protein content. Sample E had the highest amount of fat and energy content. The control sample $\mathrm{J}$ was more acceptable followed by sample A because of it colour and aroma.

\section{Ethical approval}

Ethical approval reference number RUGIPO/NUD/2020/105 was obtained for the study from the Ethic committee of the department of Nutrition and Dietetics Rufus Giwa Polytechnic, Owo, Ondo State

\section{Informed consent}

Before the sensory evaluation, each panelist was informed about the objective of the study. Verbal consent from the panelist was obtained after the objective of the study was explained to them

\section{Declaration of conflict of interest}

The authors declared no conflicts of interest. The authors alone are responsible for the design, data collection, writing and funding of this research.

\section{Author's contribution}

Ademulegun T.1, Olanrewaju, O.I and Abraham ML, contributed to the design of the study. Alebiosu Ibidayo, Adedayo, OE and Abraham M.L were involved in the purchase and processing of the complementary food samples. Olanrewaju, O.I and Abraham ML were wrote the final draft and they are responsible for the integrity of the work as a whole. All authors reviewed and edited the draft, and approved the final manuscript

\section{REFERENCES}

1. Egbujie, A.E \& Okoye, J.I. Chemical and sensory evaluation of complementary foods produced from sorghum, African yam bean and crayfish flours. International Journal of Food Science and Nutrition 2019, 4(3) 114-119

2. UNICEF. Tracking Progress on Child and Maternal Nutrition. A survival and development priority: New York, NY 10017, USA. 2009

3. Mosha T., Laswais, Tetens I. Nutritional composition and micronutrient status of homemade and commercial weaning foods consumed in Tanzania. Plant Foods Human Nutrition, 2000, 55(3): 185-205.

4. Muhimbula, H., Zacharia, I. \& Kinabo, J. Formulation and sensory evaluation of complementary foods from local, cheap and readily available cereals and legumes in Iringa, Tanzania. 
African Journal of Food Science. 2011, 5 (1): 26 31.

5. Kikafunda JK, Walker AF, Tumwine JK. (2003).Weaning Foods and Practices in Central Uganda: A cross-sectional study. African Journal Food Agriculture, Nutrition and Development, 3 (2); pp. 1-13.

6. World Health Organization: Complementary feeding: Family foods for breast feeding children, WHO, Geneva. 2000

7. Adelekan, DA. Childhood Nutrition and Malnutrition in Nigeria. Journal of Nutrition, 19 (2), pp. 2003, 179-181.

8. Ikujenlola, V.A. \& Fashakin, J.B. The physiochemical properties of complementary diet prepared from vegetable proteins. Journal of food, Agriculture environment; 2005, 3 (3 \& 4), 20-22.

9. Abiose, SH, Ikujenlola, A.V., and Abioderin, F.I. Nutritional quality Assessment of Complementary Foods Produced from Fermented and Melted Quality Protein Maize Fortified with Soybean Flour. Poland Journal Food Nutrition Sciences. 2015, 65 (1), pp.49-56.

10. Ojinaka, M.C, Ebinyasi, C.S, Ihemeje, A and Okorie, S.U. Nutritional evaluation of complementary food formulated from blends of soybean flour and ginger modified with cocoyam starch. Advanced journal of food science and technology 2013, 5(10)1325-1335

11. Yusufu, P.A., Egbunu, F.A., Egwujeh, S.I.D., Opega, G.L. and Adikwu, M.O. Evaluation of Complemtnary food prepared from sorghum, African yam bean (Sphenostytis stenocarpa) and mango mesocarp flour blends. Pakistan Journal Nutrition 2013, 12(2): 205-208.

12. Black, R. E., Victora, C. G., Walker, S. P., Bhutta, Z. A., Christian, P., De Onis, M., Ezzati, M., Grantham-McGregor, S., Katz, J., Martorell, R. \& Uauy, R. Maternal and Child Under-nutrition and Overweight in Low-Income and Middle-Income Countries." Lancet 2013, 382 (9890): 427-451.

13. World Health Organization. (2010). Summary of guiding principles for complementary feeding of the breastfed children Geneva, Switzerland.

14. Okoye, JI and Ene, GI. Evaluation of Nutritional and Organoleptic Properties of Maize-Based Complementary Foods Supplemented with Black Bean and Crayfish Flours. Global Advanced Research Journal of Food Science and Technology. 2018, 6(1) pp. 001-009

15. Igyor, MA, Yusuf, PA. \& Senger, IA. Evaluation of Phytochemical and Functional and Sensory Properties of Fermented fura powder supplemented with soy." Nigerian Food Journal, 2011, 28: 113-121.

16. Inyang $\mathrm{CU}$ and Idoko CA. Assessment of the Quality of "Ogi made from malted millet. African Journal biotechnology. 2006, 5; 2334-2337.

17. Okoye, J. I. and Ene, G. I. Evaluation of Nutritional and Organoleptic Properties of Maize-Based
Complementary Foods Supplemented with Black Bean and Crayfish Flours. Global Advanced Research Journal of Food Science and Technology. 2018, 6(1) pp. 001-009

18. Onabanjo, OO, Akinyemi CO, and Agbon CA. Characteristics of complementary foods produced from sorghum, sesame, carrot and crayfish. Journal of Natural Sciences, Engineering and Technology 2009, 8 (1):71-83

19. Ademulegun, TI. \& Koleosho, AT. Effect of processing method on the nutrients composition of maize/Soy complementary food. ISSN: 22783008. 2012, 4, 39-43.

20. Lopez, Y., Godon, D. I. \& Field, M. L. (2014). Release of phosphorus from phytate by natural lactic acid fermentation. J. Food Sci. 2014, 48: 933 -54 .

21. AOAC. Official Methods of Analysis, $19^{\text {th }}$ ed. Association Of Official Analysis Chemist, Washington, 2012

22. Ferris DA, Flores RA, Shanklin CW, Whitworth MK. Proximate analysis of food service wastes. Applied Engineering in Agriculture 1995, 11:5677225.

23. Buchholz AC, Schoeller DA. Is a calorie a calorie? America Journal of Clinical Nutrition 2004, 79; 899S-906S.

24. Nnam, NM. Evaluation of complementary foods based on maize, groundnut, paw paw and mango flour blends. Nigerian Journal of Nutritional sciences 2002, 23 (1\&2). 8-18

25. Barber LI, Obinna-Echem, PC, \& Ogburia, EM. Proximate Composition, Micronutrient and Sensory Properties of complementary food from fermented maize, soybean and carrot flours. Sky Journal of Food Science.2017 6(3): 033-039.

26. Onimawo IA \& Offurum M. Formulation and nutrient composition of maize pap fortified with groundnut flour. Nigerian journal of nutritional sciences, 2015, 36(2) 64-71

27. Okudu, HO., Ojinnaka, MC. \& Kalu, MO. "Chemical and sensory properties of complementary food produced from sorghum (sorghum bicolor), Pigeon pea (Cajanuscajan) and carrot (Daucuscarrota) blends. African journal of food science and Technology, 2017, 8 (4), pp.050055 .

28. Akubor PI. Evaluation of Physiochemical and Sensory Properties of Soybean-Sweet potato supplementary food. Journal of chemical society of Nigeria 2008, 33: 112-121

29. Onoja, US. \& Obizoba, IC. Nutrient composition and organoleptic attributes of gruel based on fermented cereal, legume, tuber and root flour. Journal of tropical Agriculture Food Environment and Extension; 2009, 8: 162-168.

30. Fasasi OS. Proximate, Anti-nutritional Factors and Functional Properties of Processed pearl millet (Pennisetumglaucum). Journal of Food Technology. 2009, 7(3): 92-97 
31. Ijarotimi SO and Olufunke OK. Determination of Nutrient Composition and Protein Quality of Potential Complementary Foods Formulated from the Combination of Fermented Popcorn, African Locust and Bambara Groundnut Seed Flour. Polish Journal of Food and Nutrition Sciences 2013, 63(3): 155-166

32. Dietary Reference Intakes for Energy, Carbohydrate, Fiber, Fat, Fatty Acids, Cholesterol, Protein, and Amino Acids (2002/2005) and Dietary Reference Intakes for Water, Potassium, Sodium, Chloride, and Sulfate (2005). The report may be accessed at www.nap.edu. Copyrighted by the National Academy of Science

33. Ojinaka, M.C, Ebinyasi, CS, Ihemeje, A \& Okorie, SU. Nutritional evaluation of complementary food formulated from blends of soybean flour and ginger modified with cocoyam starch. Advanced journal of food science and technology 2013, 5(10)1325-1335

34. Amadi, JAC, Asinobi CO, Elo-Ilo, JC, Afamanene, OC, Obiakor-okeke, P.N and Akujuobi C.I (2017). Effect of Nutrition Education of Mothers on the Anthropometric indices of preschoolers and mothers nutrition knowledge in umuguma, imo state. Nigeria. Journal of Dietitian Association of Nigeria 2017,8: 52-59

35. Matilda, A. Kjartensandnes (1993). Effect of processing (sprouting and /fermentation) on sorghum and maize: II. Vitamins and amino acid composition. Biological utilization of maize protein volume 48 (2) 201-204

36. United Nations Children Emergency Fund . How to feed a baby after 6 months. A brochure developed by University research Co., LLC in Tanzania, Kenya, Malawi and Uganda. NuLife Program: USAID Cooperative agreement 717-A00-08-00006-00. 2010

37. Amankwah, EA, Barimah J, Acheampong, R, Addai, LO. Nnaji, CO. Effect of Fermentation and Malting on Viscosity of Maize-Soyabean Weaning Blends. Journal of Nutrition 2009, 8 (10): 16711675

38. World Health Organization. Summary of guiding principles for complementary feeding of the breastfed children Geneva, Switzerland 2010

39. Akinola OO, Opreh, OP \& Hammed, IA. Formulation of local ingredient based complementary food in south-west Nigeria". Journal of Nursing and Health science 2014, 3; 2320-1940

40. Mahan, LK. \& Escott-Stump, S. (2008). Krause's Food Nutrition Therapy: Nutrition during infancy, $12^{\text {th }}$ ed. Saunders Elsevier pub.2008, pp 199-221.
41. Hounhouigan, DJ Jansen, JMM, Nout, MJR., Nago, MC., \& Rombouts, FM. Production and quality of maize-based fermented dough in Benin urban area. In: Westby A, Reilly PJA, editors. Traditional African Foods Quality and Nutrition. Stockholm: IFS. 1991, Pp. 9-8.

42. Rusydi, MRM., Noraliza, CW, Azrina, A \& Zulkhairi, A. Nutritional changes in germinated legumes and rice varieties. International Food Research Journal, 2016, 18:705-71335.

43. Arawande, J.O \& Borokini, F.B. Comparative study on chemical composition and functional properties of the three Nigeria legumes (jack beans, pigeon pea and cowpea). Journal of Emerging Trends in Engineering \& Applied sciences 2010, 1 (1)89-95

44. Butt, SM. and Batool, R. Nutritional and Functional Properties of Some Promising Legumes Protein Isolates. Pakistan Journal of Nutrition; 2010, 9, 373-379

45. Klim, F. Isaac, O. \& Joseph, JO. Feeding \& Nutrition and Infant and Young Children; Energy and micronutrients: WHO European series, 2001, $87,45-80$.

46. Michaelsen, KF., Weaver, L., Branca, F. \& Robertson, A. Feeding and nutrition of infants and young children-Guidelines for the WHO European Region, with emphasis on the former soviet countries. WHO Regional Publications, European series, 2000, 87,45-80

47. Bolarinwa IF, Olajide JO, Oke MO, Olaniyan S.A and Grace FO. Production and quality evaluation of complementary food from malted millet, plantain and soybean blends. International Journal of Scientific and Engineering Research, 2016, 7(5): 663-674

48. Oyarekwa, MA. Adeyeye, EI. Comparative evaluation of the nutritional quality, functional properties and amino acid profile of co-fermented maize/cowpea and sorghum/cowpea ogi as infant complementary food. Asian Journal of Clinical Nutrition, 20091 (1), 31- 39

49. Anigo, KM, Ameh, D.A, Ibrahim S, Daubauch, SS. Nutrient composition of complementary gruels fermented from malted cereals, soybean and groundnut for use in North Western Nigeria. African Journal of Food Science. 2010, 4(3):65-67.

50. Ibironke SI, Fashakin JB and Badmus OA. Nutritional evaluation of complementary food developed from plant and animal sources. Nutrition and Food Science ; 2012, 42(2):111-120

51. Wardlaw GM, Hampl JS. Perspective in Nutrition, $7^{\text {th }}$ ed. McGraw-Hill press, New York, 2007, 1758 . 